\title{
Öğrencilerin Okula Devamından Sorumlu Paydaşların Görüşlerine Göre Okul Devamsızlığının Nedenleri ve Buna Yönelik Çözüm Önerileri
}

\section{Reasons for School Absenteeism from Perspectives of Stakeholders Responsible for Students' School Attendance and Solution Suggestions}

Yakup BALANTEKİN ${ }^{1}$
Hülya KARTAL ${ }^{2}$
Özet: Eğitim-öğretim etkinliklerinin yürütüldüğü eğitim kurumlarının amacına uygun olarak varlığını sürdürebilmesi için öğrencilerin okula devamı önemlidir. $\mathrm{Bu}$ nedenle bu araştırmada, öğrencilerin devamsızlık nedenlerini ve öğrencilerin sürekli devamsız duruma düşmemeleri için uygulanabilecek bir programın temellerini belirlemek amaçlanmıştır. Araştırmada, nitel araştırma desenlerinden durum çalışması ve veri toplama aracı olarak katılımcıların öğrenci devamsızlığındaki sorumluluk alanlarına bağlı olarak yarı yapılandırılmış görüşme formları kullanılmıştır. Veriler içerik analizi tekniğiyle değerlendirilmiştir. Araştırma sürecinde, sürekli devamsız öğrencilerin ailelerinin sosyo-ekonomik düzeyinin düşük olduğu; bu öğrencilerin annelerinin okuryazar olmadığı, babaların ise ilk ve ortaokul mezunu olduğu; öğrencilerin okula devamı için sıklıkla devamsızlık mektubu gönderildiği ve ev ziyareti yapıldığı; öğrencilerin sürekli devamsız duruma gelmelerinin nedenleri arasında en sıklıkla öğrencilerin başarısız olmaları ve arkadaş grubunun olduğu; okula devamın sağlanması konusunda tüm tarafların katkısının olduğu sonucuna ulaşılmıştır. Ayrıca katılımcıların büyük çoğunluğunun mevzuat çerçevesinde yapılanları yeterli bulmadığg; öğrencilerin okula devamının sağlanması için katılımcıların önerileri arasında ilk sırada cezai yaptırımların uygulanmasının olduğu, bunu ikinci sırada devamsızlık konusunda yol gösterici bir program uygulanması, öğrenci adreslerinin erişilebilir olması ve ailelere yönelik eğitimler verilmesinin izlediği; öğrencilerin sürekli devamsız duruma düşmesini engellemek için hazırlanacak bir program ya da projenin okul yaklaşımı, okul ortamı, aile ve öğrenci temalarını içermesi gerektiği belirlenmiştir.
Abstract: In order for educational institutions, where educational activities are performed, to continue their existence in line with their goals, it is important that students should attend schools. For this reason, in this study, it was aimed to investigate reasons for student absenteeism and determine bases of intervention programs to implement with the aim of preventing student nonattendance. The study employed the method of case study, one of the qualitative research designs, and used semistructured interview forms as data collection tools depending on the participants' responsibility areas in student absenteeism. The data were evaluated via the content analysis technique. During the study, the following results were reached: the socio-economic levels of the families of the habitually absent students were low; these students' mothers were illiterate and their fathers were primary or secondary-school graduates; warning letters for absenteeism were frequently sent to achieve the students' school attendance and home visits were made; among the primary reasons for the students' habitual absenteeism were their frequently being unsuccessful and having a friends' group; all the parties had important contributions to the achievement of school attendance. Moreover, the great majority of the participants found what was done within the framework of regulations insufficient; most of the participants suggested the followings to achieve the students' school attendance: firstly penal sanctions should be applied; secondly, students should be given an instructive program about the matter of absenteeism; students' addresses should be accessible and families should be given trainings; a program or a project to be prepared with the aim of preventing students' habitual absenteeism should include school approach, school environment and the themes of student and family.

Keywords: School, dropout of school, discontinuity, intervention program

\section{Anahtar Kelimeler: Okul, okul terki, devamsızlı, müdahale programı}

\section{Giriş}

\footnotetext{
${ }^{1}$ Dr. Bursa Yıldırım İlçe Milli Eğitim Müdürlüğü

${ }^{2}$ Doç. Dr. Uludağ Üniversitesi Eğitim Fakültesi Ilköğretim Bölümü Öğretim Üyesi
} 
Bireyin gelişimi için gerekli olan öğrenme sürecinin sistemli bir şekilde yürütülmesi için ihtiyaç duyulan eğitim kurumları (Demirel, 2004, 221) İlkokul Programı'nda (1948, s.6) ‘ögrenci, öğretmen ve yöneticileriyle birlikte ailenin de katıldiğg bir insan topluluğunun; işbirliği, yardımlaşma ve sorumluluk duygularlyla birbirine bağlandiğl ve birbirlerinin sevincini, kederlerini ve yaşantılarını ve bilgilerini paylaştı̆̆ ve gerçek bir hayat safhası' olarak tanımlanmaktadır (Akt. Binbaşığlu, 1995). Bu kapsamda bireyin akran, ebeveyn ve eğitimcilerin birbirleri ile kurdukları ilişki ağı içinde gelişimi ve bu gelişiminin sonunda oluşacak toplumsal gelişimi sağlamak amaciyla yürütülen eğitim-öğretim sürecinin verimli ve amacina uygun bir biçimde yürütülebilmesi için bu sürecin merkezinde olan öğrencilerin okula devamının ayrı bir önemi vardır.

Okulların gerçek bir hayat safhası olduğu düşünüldüğünde öğrenci merkezli eğitim bağlamında öğrencinin içinde bulunmadığı bir eğitim-öğretim etkinliği onun bir yaşam deneyiminden yoksun kalması anlamına gelmektedir (Özbaş, 2010). Bu yoksunluk birey ve topluma zarar vererek öğrenim düzeyi düşük olan ebeveynlerin yaygınlaşmasına yol açacak ve ülkenin geleceğini de riske sokacaktır.

Teasley'e göre (2004), devamsızlık probleminin ortaya çıkmasında ve bu problemin devam etmesinde birçok faktör birlikte rol oynayabilir. Bu faktörler arasında; toplum desteğinden yoksun olma, destekleyici olmayan bir okul ortamı, aile yaşantısının düzgün olmaması, kötü hava şartları ve ulaşım problemleri, sağlık problemleri ve kişisel yetersizlikler bulunmaktadır (Akt. Şanlı ve diğ. 2015). Bunun yanı sıra Kinder, Wakefield ve Wilkin (1995), arkadaş ortamı, öğretmenlerle ilişkilerin zayıf olması, ailesel durumları ile zorbalık ve sınıf ortamının devamsızlık üzerinde etkili olduğunu belirlemiştir (Akt. Şanlı ve diğ. 2015).

Hoşgörür ve Polat (2015) tarafindan ortaokulda öğrenim görmekte olan öğrencilerin devamsızlık yapma nedenlerinin belirlenmesine yönelik araştırmada öğrencilerin devamsızlık yapmasında aileden kaynaklanan nedenlerin ilk sırada yer aldığı, bunun yanı sıra kişisel, sağlık ve arkadaş grubundan kaynaklanan nedenlerin de etkili olduğu belirlenmiştir. Yine Gömleksiz ve Özdaş (2013) tarafindan eğitim denetmenleri ile öğrenci devamsızlığının değerlendirildiği araştırmada, velilerin eğitime olumsuz yaklaşmaları, okulların ve sınıfların fiziki durumlarının yetersiz olması, ailelerin ekonomik yetersizlikleri gibi nedenlerin öğrenci devamsızlığında etkili olduğu sonucuna ulaşılmıştır.

Haberli ve Güvenç (2012) tarafindan ortaokul öğrencilerinin okula devamsızlık nedenlerini tespit etmek ve devamsızlı nedenlerinin cinsiyete göre farklı1ıklarını ortaya koymak amaciyla yapılan araştırmada öğrencilerin devamsızlıklarının yoğun olarak ailevi nedenlerden kaynaklandığı ve cinsiyete göre devamsızlık nedenlerinde de önemli farklılıklar olduğu tespit edilmiştir. Yıldız (2011) tarafından ortaokul öğrencilerinin devamsızlık nedenlerini tespit etmek amacıyla yapılan araştırmada öğretmen ve aile tutumları, öğrencilerin sağlık sorunları ve çevresel etkenlerin öğrenci devamsızlığında etkili olduğu tespit edilmiştir.

Unicef Türkiye Temsilciliği ve Eğitim Reformu Girişimi tarafından imzalanan Program İşbirliği Anlaşması uyarınca Milli Eğitim Bakanlığı Temel Eğitim Genel Müdürlüğü işbirliğinde Öğrenci Devamsızlığının Belirleyicileri ve Ekonomik Krizle İlişkisi araştırmasında, ülkemizde yıllar ilerledikçe hızlı bir biçimde mazeretsiz devamsızlığın arttığı özellikler ortaokul öğrencilerinin devamsızlık oranlarının ilkokul öğrencilerine göre daha fazla olduğu tespit edilmiştir (İlköğretimde Öğrenci Devamsızlığının Azaltılması, 2015).

Lan ve Lanthier (2003) öğrencilerin okulu terkinin "önce, okul kuralları ve normlarından sapmalar (okula yabancılaşmak), daha sonra okul faaliyetlerine katılmama, okulda başarısız olma ve sonunda da okuldan ayrılma" gibi evrelerden oluşan "aşamalı" uzun bir süreç sonunda gerçekleştiğini belirtmiştir 
(Akt. Sütçü, 2015:26). Bu kapsamda öğrencilerin okul kurallarına uymamaları, okul faaliyetlerine, derslere katılmamaları, aralıklı devamsızlık yapmaları ve bütün bunlara bağlı olarak oluşacak akademik başarısızlık öğrencilerin okulu terk etme noktasına gelebilecekleri konusunda eğitimcilere önceden ipucu vermektedir. Bir yönüyle bu ipucu, öğrencilerin eğitim-öğretim sürecinden kopmamaları için gerekli müdahale programlarının uygulanmasını gerekli kılmaktadır. Bütün bu veriler ışığında bu araştırmada, öğrencilerin devamsızlık nedenlerini ve öğrencilerin sürekli devamsız durumuna düşmemeleri için uygulanabilecek müdahale programının temellerini belirlemek amaçlanmıştır. Ülkemizde öğrenci devamsızlığı ile ilgili yapılan çalışmalar genel olarak devamsızlığın nedenlerini belirlemeye yönelik olup bu araştırmada okul devamsızlığının nedenleri, Milli Eğitim Bakanlığı'nın öğrencilerin okula devamını sağlamak için yükümlü kıldığı farklı konumlardaki görevlilerin görüşlerine göre ele alınmış ve daha önemlisi bu durumu ortadan kaldırmak için bahsi geçen görevlilerin çözüm önerileri ortaya konmuştur.

\section{Yöntem}

\section{Araştırma Deseni}

$\mathrm{Bu}$ çalışmada, öğrencilerin okula devamını engelleyen nedenleri, mevzuat çerçevesinde yapılanların yeterliliğini ve okula devam sorunu yaşayan öğrencilerin okula devamını sağlayabilecek uygulamaları öğrencilerin devamından sorumlu olan kişilerin görüşleri doğrultusunda belirlenmesi amaçlanmıştır. Çalışmanın amaçları doğrultusunda, nitel araştırma desenlerinden durum çalışması kullanılmıştır. $\mathrm{Bu}$ desende bir ya da daha çok durum, durumla ilişkili etkenler ile bütüncül bir yaklaşımla ayrıntılı olarak araştırılmaktadır. Durum çalışması nasıl ve niçin sorularından hareketle araştırmacı tarafından kontrol edilemeyen olgu ya da olayların araştırmacı tarafından derinlemesine incelenmesine olanak tanımaktadır (Yıldırım ve Şimşek, 2008).

Çalışma Grubu

İlköğretim ve Eğitim Kanunu'nun (1961) Okula Devam kısmında okul yönetimi, maarif müfettişleri, muhtarlar ve mülki amirlerin öğrencilerin okula devamlarından sorumlu oldukları belirtilmektedir. Buradan hareketle çalışma grubu, ilgili kanunun sorumlu kıldığı kişilerden oluşturulmuştur. Bu şekilde öğrenci devamsızlığının izlenmesi konusunda sorumluluğu olduğu düşünülen tüm yetkililere/paydaşlara ulaşılmaya çalışılmıştır. $\mathrm{Bu}$ nedenle çalışma grubu amaçlı örnekleme yöntemlerinden maksimum çeşitlilik örneklemesine göre oluşturulmuştur. Bu örnekleme türünde probleme taraf olabilecek bireylerin çeşitliliğini sağlamak amaçlanmaktadır(Yıldırım ve Şimşek, 2008, 77). Çalışma grubunda yer alan rehber öğretmenler tablolarda "RÖ", müdür yardımcıları "MY", şube müdürleri "ŞM", müfettişler "MÜF" ve muhtaralar ise "MUH" olarak kısaltma şeklinde verilmiştir. Çalışma grubunun özellikleri aşağıda Tablo 1'de verilmiştir.

Tablo 1. Çalışma Grubunun Özellikleri

\begin{tabular}{|c|c|c|c|c|c|c|c|}
\hline Görevi & $\begin{array}{l}\text { Cin } \\
\text { siyet }\end{array}$ & $\begin{array}{c}\text { Kıdem } \\
(\mathrm{y} 1 \mathrm{l})\end{array}$ & $\begin{array}{c}\text { Öğrenci } \\
\text { Sayısı }\end{array}$ & $\begin{array}{c}\text { Görüşme } \\
\text { Sayısı }\end{array}$ & $\begin{array}{c}\text { Sürekli } \\
\text { Devamsız } \\
\text { Öğrenci } \\
\text { Sayısı } \\
\end{array}$ & $\begin{array}{l}\text { Kardeş } \\
\text { sayısı }\end{array}$ & $\begin{array}{c}\text { Ziyaret } \\
\text { edilen } \\
\text { okul } \\
\text { sayısı } \\
\end{array}$ \\
\hline RÖ & $E$ & 9 & 830 & 50 & 40 & $5-6$ & \\
\hline RÖ & K & 1 & 1600 & 10 & 200 & $3+$ & \\
\hline RÖ & $\mathrm{K}$ & 3 & 2030 & 75 & 240 & $5-6$ & \\
\hline MY & E & 5 & 2030 & 160 & 240 & $5-6$ & \\
\hline MY & E & 1 & 830 & $70-80$ & 40 & $5-6$ & \\
\hline MY & K & 8 & 1600 & 150 & 200 & $3+$ & \\
\hline MY & E & 1 & 957 & $45-50$ & 80 & $4-5$ & \\
\hline ŞM. & E & 1 & & & & & \\
\hline ŞM & E & 15 & & & & & \\
\hline ŞM & E & 14 & & & & & \\
\hline
\end{tabular}




\begin{tabular}{|c|c|c|c|}
\hline SM & $\mathrm{E}$ & 14 & \\
\hline MÜF & E & 11 & 30 \\
\hline MÜF & E & 16 & 35 \\
\hline MUH & $\mathrm{E}$ & 2 & \\
\hline MUH & E & 11 & \\
\hline
\end{tabular}

\section{Veri Toplama Araçları}

Araştırma verileri, çalışma grubunu oluşturan katılımcıların öğrenci devamsızlığındaki sorumluluk alanlarına bağlı olarak rehber öğretmenler ve devamsızlık işlemlerinden sorumlu müdür yardımcıları, muhtarlar, maarif müfettişleri ve şube müdürlerine yönelik yarı yapılandırılmış görüşme formlarıyla toplanmıştır. Müdür yardımcıları ve rehber öğretmenlere yönelik hazırlanan görüşme formları aynı formlar olup yedi sorudan; muhtarlara yönelik hazırlanan görüşme formları yedi sorudan; müfettişlere yönelik hazırlanan görüşme formu beş sorudan; şube müdürlerine yönelik hazırlanan görüşme formu üç sorudan oluşmaktadır. Görüşme formları bir öğretim üyesi, iki şube müdürü, bir rehber öğretmen ve bir müdür yardımcısının görüşleri alınarak hazırlanmıştır. Katılımcılara yöneltilen sorular onların görev alanlarıyla ilgilidir. Örneğin müdür yardımcısı ve rehber öğretmenlere 'Öğrencilerin sürekli devamsız duruma gelmelerinin nedenleri nelerdir?' sorusu yöneltilirken şube müdürlerine 'Devamsız öğrencilerle ilgili okullar hangi işlemleri yapmaktalar?' muhtarlara 'Devamsızlık yapan öğrencilerle ilgili okul yönetimleri sizlerden neler talep etmektedirler?' sorusu yöneltilmiştir.

Veriler daha önceden randevu alarak katılımcıların çalıştıkları kurumlarda uygun çalışma odalarında gerçekleştirilmiştir. Randevu alırken katılımcılara konu hakkında bilgi verilerek katılımcıların zihinsel olarak görüşmeye hazır olması sağlanmıştır.

\section{Verilerin Analizi}

Veriler, içerik analizi tekniğiyle çözümlenmiştir. Cole'ye (1998) göre Bu yöntemle sözlü veya görsel mesajların yazıya dökülerek çözümlenmesi amaçlanmıştır (Akt. Elo ve Kynigas, 2008). Araştırmada yer alan Şube Müdürleri (ŞM), Rehber Öğretmen (RÖ), Müdür Yardımcısı (MY), Müfettiş (MÜF) ve Muhtarların (MUH) görüşmede sorulara verdiği yanıtlar, araştırmacılar tarafından içerik analizi yöntemiyle çözümlenmiştir. Bu çözümleme birkaç adımda gerçekleşmiştir. Her görüşmenin içeriği (metin) yani sorulara verilen her bir yanıt araştırmacı tarafından tekrar tekrar okunarak sorunun yanıtı tam olarak analiz edilmeye çalışılmıştır. Bütün yanıtlar cümle cümle, sözcük sözcük alt alta sıralanarak ortak veya benzer ifadeler gruplandırılmış ve bu gruplandırmaları temsil eden kategoriler oluşturulmuştur. Kategoriler altında yer alan maddelerin sayısal olarak görülme sıklı̆̆ı bu maddenin yoğunluğunu ve önemini anlamayı sağlayan (Bilgin, 2006) içerik analizi tekniklerinden frekans analizi tekniğiyle belirlenmiştir.

Geçerlik ve Güvenirlik

$\mathrm{Bu}$ araştırmada geçerlik ve güvenirliği artırmak için aşağıdaki önlemler alınmıştır:

(i) Araştırmacılar tarafından ilgili alan yazın incelemesi yapılmış (Aküzüm, Yavaş, Tan, ve Uçar, 2015; Baruah \& Goswami, 2012; Cabus, 2015; Gömleksiz \& Özdaş, 2013; Haberli \& Güvenç, 2012; Hoşgörür \& Polat, 2015; Mercan Uzun, \& Bütün, 2015; Köse, 2014; Okumu, Nakajjo \& Isoke, 2008; Rumberger Russell, 2001; Sütçü, 2015; Okuşluk Çapur, 2006; Özbaş, 2010; Şanlı Kula \& Yıldız, 2014; Şanl1, Altun \& Tan, 2015), çalışmayla ilgili kavramsal çerçeve oluşturulmuştur. Veri toplama araçları kavramsal çerçeve 1şığında ve ilçe milli eğitim müdürlüklerinde devamsızlıkla ilgilenen iki şube müdürü, bir öğretim üyesi, ilgili bir müdür yardımcısı ve rehber öğretmenin görüşleri alınarak hazırlanmıştır. 
(ii) Aynı okulda görev yapan müdür yardımcısı ve rehber öğretmenlerle görüşme yapmaya çalış1lmış ve bu bağlamda veriler karşılaştırılmıştır.

(iii) Çalışmanın güvenirliğini artırmak için çalışma süreci ve bu süreçte yapılanlar ayrıntılı bir biçimde açıklanmıştır.

(iiii) Görüşme sonunda oluşan metinler görüşülenlerle paylaşılarak teyit edilmiştir.

\section{Bulgular}

Araştırma sürecinde toplanan verilerden elde edilen bulgular aşağıda sunulmuş olup katılımcıların öğrencilerin sosyo-ekonomik düzeylerine ilişkin görüşleri Tablo 2'de gösterilmiştir.

Tablo 2. Katılımcıların Öğrencilerin Sosyo-Ekonomik Düzeyine İlişkin Görüşleri

\begin{tabular}{|c|c|c|c|c|}
\hline $\begin{array}{l}\text { Sürekli devamsız ögrrencilerin ailelerinin sosyo- } \\
\text { ekonomik düzeyi nedir? }\end{array}$ & MÜF & MY & RÖ & MUH \\
\hline Düşük düzeyde & 2 & 3 & 3 & 2 \\
\hline Çocuklarını çalıştırmak zorunda kalacak kadar düşük & & 1 & 1 & \\
\hline Babası işsiz & & & 1 & \\
\hline Göçle gelmeleri & & 1 & & \\
\hline Ekonomik durumu iyi olanın da kötü olanın da olması & & 2 & & \\
\hline
\end{tabular}

Tablo 2 incelendiğinde, araştırmaya katılanların büyük çoğunluğunun görüşlerine göre sürekli devamsız öğrencilerin ailelerinin sosyo-ekonomik düzeyinin düşük olduğu; bunun yanı sıra katılımcılardan birinin sürekli devamsız öğrencilerin babasının işsiz olduğunu belirttiği görülmektedir. Buna karşın rehber öğretmen ve müdür yardımcılarından birisinin sürekli devamsızlık yapan öğrencilerin ailelerinden sosyoekonomik düzeyi iyi olanların da kötü olanların da olduğunu belirttiği dikkat çekmektedir.

Katılımcıların, öğrencilerin ailelerinin eğitim düzeyine ilişkin görüşleri Tablo 3'de verilmiştir.

Tablo 3. Katılımcıların, Öğrencilerin Ailelerinin Eğitim Düzeyine İlişkin Görüşleri

\begin{tabular}{llll}
\hline Sürekli devamsız öğrencilerin ailelerinin öğrenim düzeyi & RÖ & MY & MUH \\
\hline Okuryazar olmayan anneler & 3 & 2 & 2 \\
Okuryazar olmayan veliler & 1 & & 1 \\
Okuryazar & - & & 2 \\
Genelde İlkokul & 1 & 1 & \\
İlkokul mezunu baba & 1 & 2 & \\
Ortaokul mezunu baba & 1 & 2 & \\
\hline
\end{tabular}

Tablo 3'de görüldüğü gibi araştırmaya katılan rehber öğretmen, müdür yardımcısı ve muhtarlar, sürekli devamsız olan öğrencilerin özellikle de annelerinin okuryazar olmadığını belirtirken babaların ise ilk ve ortaokul mezunu olduğunu belirtmişlerdir.

Katılımcılara göre öğrencilerin sürekli devamsız durumuna gelme nedenlerine ilişkin veriler Tablo 4'de verilmiştir.

Tablo 4. Katılımcılara Göre Öğrencilerin Sürekli Devamsız Durumuna Gelme Nedenleri

\begin{tabular}{llllllll}
\hline $\begin{array}{l}\text { Öğrencilerin sürekli } \\
\text { gelmelerinin nedenleri }\end{array}$ & devamsız duruma & RÖ & MY & MÜF & MUH \\
\hline
\end{tabular}




\begin{tabular}{|c|c|c|c|c|}
\hline Derste başarısız olmaları & 1 & 3 & 2 & \\
\hline Arkadaş grubu & 2 & 3 & & 1 \\
\hline Velilerin çocuklarını çalıştırması & 1 & 1 & 2 & 1 \\
\hline Maddi imkansızlık & 1 & 1 & & 1 \\
\hline Velilerin çocuktan ümidini kesmesi & 2 & & & \\
\hline Alay edilmesi & 1 & 1 & & \\
\hline Kız çocuklarını 4+4+4'den etkilemesi & & 1 & & \\
\hline Okuma-yazma bilmemeleri & 1 & & & \\
\hline Ailenin ilgilenmemesi & & 1 & & \\
\hline Parçalanmış ailelerin çocukları olması & & & 1 & \\
\hline Kız çocuklarının okutulmak istenmemesi & & 1 & & \\
\hline Göçle gelinmesi & & 1 & & \\
\hline Okulun istenmemesi & 1 & & & \\
\hline Çocuğun çalışması & & 1 & & \\
\hline $\begin{array}{l}\text { Babanın cezaevinde olması nedeniyle ziyarete } \\
\text { gidildiği günler okula gelinememesi }\end{array}$ & & 1 & & \\
\hline Ailelerin çocuklarına ev işleri yaptırması & & & 1 & \\
\hline
\end{tabular}

Tablo 4'de görüldüğü gibi “Öğrencilerin sürekli devamsız duruma gelmelerinin nedenleri nelerdir?" sorusuna katımcıların verdiği yanıtların arasında en sıklıkla öğrencilerin derslerde başarısız olmaları ve arkadaş grubu görülmektedir. İkinci sırada velilerin çocuklarını çalıştırması, üçüncü sırada ise öğrencilerin maddi imkansızlıklarının olması yer almaktadır. Velilerin çocuklarını çalıştırdığı için öğrencilerin sürekli devamsız duruma geldiğini belirten katılımcılardan muhtar düşüncesini "Velilerin bilinçli olarak çalışmaya gönderip okula göndermemesi" (MUH1) şeklinde ifade ederken, bir müfettiş de "Veliler özellikle çocuğunun okulda başarısız olduğuna inanmışsa, gitse ne olur diye düşünüp kısa vadede çocuktan verim alabilmek için çocukları işe gönderiyor. Vatandaş çocuğunu on iki yıl okula gönderiyor fakat sonuçta çocuk iş sahibi olmayınca okulun veli gözünde önemi kalmıyor." (MÜF2) şeklinde belirtmiştir. Katılımcılardan ikisi nedenler arasında öğrencilerle alay edilmesini belirtmiştir. $\mathrm{Bu}$ nedenle ilgili olarak rehber öğretmen "Öğrenciler özelliklerinden dolayı arkadaşları tarafindan alay edildiği veya isim/soy isimleriyle alay edildiği için devamsızlı yapıyor." (RÖ2) düşüncelerini bu şekilde ifade etmiştir. Katılımcılardan parçalanmış ailelerin çocuklarının sürekli devamsız duruma geldiğini belirten müfettiş bu konuda düşüncelerini "Bu aileler de örneğin çocuk annede ise babası ile birlikte olduğunda baba daha özgür birakıyor, anne baba davranışları arasında ki tutarsızlık çocuğu etkiliyor." (MÜF1), şeklinde ifade etmiştir. Katılımcılardan derslerdeki başarısızlığın öğrencilerin sürekli devamsız duruma gelmesine neden olduğunu belirten müfettiş bununla ilgili düşüncelerini "Ayrıca ögretmenlerin değerlendirme sürecinde tüm öğrencileri standart biçimde değerlendirmesi, onların ilgi ve yeteneklerinin göz ardı edilmesi öğrencileri başarısızlı̆ga bu da devamsızliğa sevk ediyor. Fen Liselerinde devamsızlık hiç yok, Anadolu Liseleri kısmen öyle, ancak Meslek Liselerine gelince artıyor. Sebebi akademik başarı durumu. Öğrenci derste başarısız oluyor, ondan sonra nasıl okula gelsin, ögretmenlerinin gözünde önemsiz kendini önemsiz hissediyor, arkadaşlarının davranışları, dalga geçmesi de cabası." (MÜF2), bu şekilde belirtmektedir.

Öğrencilerin okula devamını sağlamak için okul yönetimleri tarafından yapılanlara ilişkin veriler Tablo 5'de verilmiştir.

Tablo 5. Öğrencilerin Okula Devamını Sağlamak İ̧̧in Okul Yönetimleri Tarafindan Yapılanlar

\begin{tabular}{llllc}
\hline $\begin{array}{l}\text { Sürekli devamsız öğrencilerin okula devam etmesi } \\
\text { için okul yönetimlerinin yaptıkları }\end{array}$ & Rö & MY & ŞM & MÜF \\
\hline Devamsızlık takibi yapılması & 1 & 2 & & 2 \\
Devamsızlık mektubu gönderilmesi & 2 & 2 & 3 & 2 \\
Aileyle telefonla görüşülmesi & & & 2 & \\
Görüş̧me için velinin okula davet edilmesi & 2 & 3 & 1 & \\
Ev ziyareti yapılması & &
\end{tabular}




\begin{tabular}{lccc}
\hline $\begin{array}{l}\text { Öğrenci ve velilerle görüşülmesi } \\
\text { Velilerle görüşülmesi }\end{array}$ & 3 & 1 & 2 \\
$\begin{array}{l}\text { Rehber öğretmene yönlendirilmesi } \\
\text { İlçe Milli Eğitim Müdürlüğünün yazılı olarak } \\
\text { bilgilendirmesi }\end{array}$ & 1 & 4 & 1 \\
$\begin{array}{l}\text { Resmi işlemler yapılması } \\
\text { Muhtardan destek alınması }\end{array}$ & & & \\
$\begin{array}{l}\text { Mahallede sözü geçenlerden destek alınması } \\
\text { Para cezasiyla ilgili işlemler yapılması }\end{array}$ & 1 & 2 & \\
\hline
\end{tabular}

Tablo 5'de görüldüğü gibi katılımcılar, sürekli devamsız öğrencilerin okula devam etmesi için en sıklıkla devamsızlık mektubu gönderildiğini ve ev ziyareti yapıldığını belirtmektedir. Bunu ikinci sırada veliyle görüşülmesi ve İlçe Milli Eğitim Müdürlügünün yazılı olarak bilgilendirmesi izlerken; üçüncü sırada ise aileyle telefonla görüşülmesi ve öğrenci/velilerle görüşülmesi yer almaktadır. Ayrıca rehber ögretmenlerin tamamı ve müdür yardımcılarının üçü sürekli devamsız öğrencilerin okula devamı için aileden annelerle görüşme yaptıklarını belirtmiştir.

Öğrencilerin okula devamını sağlamada katkısı olanlara ilişkin veriler Tablo 6' da verilmiştir.

Tablo 6. Öğrencilerin Okula Devamını Sağlamada Katkısı Olanlar

\begin{tabular}{lcc}
\hline $\begin{array}{l}\text { Görüşme sonunda öğrencilerin okula devamlarının sağlanmasında katkısı } \\
\text { olanlar }\end{array}$ & RÖ & MY \\
\hline Müdür Yardımcısı & 2 & 1 \\
Rehber öğretmen & 2 & \\
Velinin katkısı & & 2 \\
Sinı Öğretmeni & 1 & 1 \\
Toplum polisi & & 1 \\
Okul yönetimi & & \\
\hline
\end{tabular}

Tablo 6'da görüldüğü gibi görüşme sonunda öğrencilerin okula devamları konusunda müdür yardımcılarından biri sürekli devamsız öğrencilerin devamının sağlanamadığını belirtirken diğer müdür yardımcıları ve rehber öğretmenler sürekli devamsız öğrencilerin devamının sağlandığını belirtmektedir. Öğrencilerin devamının sağlanmasında en çok aile ziyaretlerinin etkili olduğu (RÖ2;RÖ3;MY1) görülmektedir. Öğrencilerin kıyafet gereksinimlerinin karşılanmasının da okula devamı sağladığı belirtilmiştir (MY3). Ayrıca bu konuda görüşmelerin erkek çocuklara göre kız çocukların okula devamında daha etkili olması (MY1;MY4) dikkat çekmektedir. Bunların yanı sıra okula devamın sağlanması konusunda toplum polisi dahil olmak üzere tüm tarafların katkısının olduğu görülmektedir.

Katılımcıların öğrencilerin okula devamlarının sağlanabilmesi mevzuatın yeterliliği hakkındaki görüşlerine ilişkin veriler Tablo 7'de verilmiştir.

Tablo 7. Katılımcıların Öğrencilerin Okula Devamlarının Să̆lanabilmesi Mevzuatın Yeterliliği Hakkındaki Görüşleri

\begin{tabular}{|c|c|c|c|c|}
\hline \multicolumn{5}{|c|}{ Öğrencilerin okula devamlarının sağlanabilmesi için mevzuat çerçevesinde yapılanların yeterliliği } \\
\hline & RÖ & MY & ŞM & MÜF. \\
\hline Yeterli & - & - & 1 & 1 \\
\hline $\begin{array}{l}\text { Yeterli } \\
\text { değil }\end{array}$ & 3 & 4 & 3 & 3 \\
\hline
\end{tabular}

Tablo 7'de görüldüğü gibi araştırmaya katılanlardan sadece bir şube müdürü ve bir müfettişin "Öğrencilerin okula devamlarının sağlanabilmesi için mevzuat çerçevesinde yapılanlar yeterli midir?" 
sorusuna "yeterli" yanıtını verdikleri görülmektedir. Bu durum katılımcıların büyük çoğunluğunun mevzuat çerçevesinde yapılanların yeterli olmadığını düşündügünü göstermektedir. Katılımcılardan mevzuat çerçevesinde yapılanların "zorlayıcılık" yönünden yeterli olduğunu belirten şube müdürü (ŞM2), "fayda" yönünden ise yeterli olmadığını belirtmiştir. Müfettişlerden yeterli bulan katılımcı (MÜF.1) "Ancak uygulayıclların mevzuatı verimli biçimde uygulaması önemli." şeklinde düşüncelerini ifade etmiştir.

Katılımcıların, öğrencilerin okula devamını sağlamak için önerileri hakkındaki veriler Tablo 8'de verilmiştir.

Tablo 8. Katılımcıların, Öğrencilerin Okula Devamını Sağlamak İçin Önerileri

\begin{tabular}{lcc}
\hline $\begin{array}{l}\text { Öğrencilerin okula devamlarının sağlanabilmesi için mevzuat çerçevesinde yapılanlar } \\
\text { yeterli değilse yapılabilecekler }\end{array}$ & RÖ & MY \\
\hline Cezai yaptırımlar uygulanması & 3 & 1 \\
Devamsızlık konusunda idarecilere yol gösterici bir program uygulanması & & 2 \\
Öğrenci adreslerinin erişilebilir olması & & 2 \\
Aileye yönelik eğitimler verilmesi & 1 & 1 \\
Ev ziyaretlerine il/ilçe milli eğitim müdürlüklerinden yetkililerin de katılması & 1 & 1 \\
E-okulun devamsıllğı otomatik olarak bildirmesi & & 1 \\
Öğretmen-öğrenci birlikte turnuvalar yapılması & & 1 \\
Okulda internet kullanımının sağlanması & & 1 \\
Ev ödevlerini okulda yapma imkânı verilmesi & & 1 \\
Okullarda öğrenci sayısının azaltılması & & \\
Tam gün eğitimin yaygınlaştırılması & 2 & 4 \\
\hline Diğer paydaşlardan (muhtar, müfettiş, ilçe milli eğitim) beklentiler & 2 \\
\hline Cezai uygulamalar için yaptırımların olması & & 1 \\
Yapılan ev ziyaretlerin il/ilçe milli eğitimden müdürlüklerinden yöneticilerin de katılması & \\
Devamsızlık mektuplarının ilçe milli eğitim müdürlükleri kanalıyla gönderilmesi &
\end{tabular}

Tablo 8'de görüldüğü gibi “Öğrencilerin okula devamlarının sağlanabilmesi için mevzuat çerçevesinde yapılanlar yeterli midir?" sorusuna rehber öğretmen ve müdür yardımcılarının hepsinin "yeterli değil”" şeklinde yanıt vermiştir. Katılımcıların "Eğer yeterli değilse, neler yapılabilir?” sorusuna verdikleri yanıtlar incelendiğinde, ilk sırada cezai yaptırımların uygulanması olduğu görülmektedir. İkinci sırada ise müdür yardımcılarının devamsızlık konusunda yol gösterici bir program uygulanması, öğrenci adreslerinin erişilebilir olması ve ailelere yönelik eğitimler verilmesini istedikleri belirlenmiştir. Ayrıca yine aynı sıklıkla hem bir rehber öğretmen hem de bir müdür yardımcısı tarafindan ev ziyaretlerine milli eğitim müdürlüklerinden yetkililerin katılması ve e-okulun devamsızlığı otomatik olarak velilere bildirmesi gerektiği belirtilmiştir. Müfettişlerden "mevzuatın yeterli olduğunu" belirten katılımcı bu konuda "Ancak uygulayıcıların mevzuatı verimli biçimde uygulaması önemli. Ayrıca ilçe milli eğitim müdürlükleri ve müfettişler okulların devamsızlıkla ilgili iş ve işlemlerini daha düzenli kontrol etmelidir. Ayrıca para cezasının uygulanması da etkili olabilir." (MÜF.1), şeklinde beklentilerini ifade ederken; "yeterli olmadığını" belirten katılımcı ise beklentilerini "Okulda ihtiyaç sahibi öğrencilere destek olunmal, veli bilinçlendirilmeli, değerlendirme kriterleri esnek ve çocuğun yetenek ve ilgilerine göre olmalı. Değerlendirme de eşitlik değil adalet aranmalı eşitlik adalet değildir." (MÜF2), şeklinde belirtmiştir. Bu açıklamalarla katılımcılar aslında "Öğrencilerin sürekli devamsız duruma düşmesini engellemek için hazırlanacak bir program ya da projede neler olmalıdır?" sorusuna daha sorulmadan bir şekilde yanıt vermişlerdir. $\mathrm{Bu}$ nedenlerle sorulacak soru, konu hakkındaki gereksinimi ortaya koyması bakımından ayrı bir önem taşımaktadır.

Rehber öğretmen ve müdür yardımcıları mevzuat konusunda "Diğer paydaşlardan (muhtar, müfettiş, ilçe milli eğitim) beklentiniz nelerdir?" sorusuna yanıt verirken ilk sırada cezai uygulamalar için 
yaptırımların olmasını belirtmiştir. Bu konuda katılımcılardan bir müdür yardımcısı şunları belirtmiştir: "Para cezası ile ilgili veliler hocam hiç para cezası gelen duymadım diyerek geçiştiriyor. Para cezası uygulanmıyor. Uygulanması lazım. En azından birkaç kişiye uygulanması gerekir. Para cezasının caydırıcı olacağına inanıyorum." (MY4). Ardından ev ziyaretlerine il/ilçe milli eğitim müdürlüklerinde görev yapan yöneticilerin katılması ve devamsızlık mektuplarının ilçe milli eğitim müdürlüğ̈ kanalıyla gönderilmesi gelmektedir.

Öğrencilerin sürekli devamsız duruma düşmesini engellemek için hazırlanacak programın içeriğine yönelik temaları gösterir bilgiler Tablo 9'da sunulmuştur. 
Tablo 9. Öğrencilerin Sürekli Devamsız Duruma Düşmesini Engellemek İçin Hazırlanacak Programın İçeriğine Yönelik Temalar TEMA TEMA

TEMA

TEMA

TEMA

\begin{tabular}{|c|c|c|c|c|c|c|c|c|c|c|c|c|c|c|}
\hline OKULUN YAKLAŞIMI & RÖ & MY & $\begin{array}{l}\text { OKULUN } \\
\text { YAKLAȘIMI }\end{array}$ & RÖ & MY & $\begin{array}{l}\text { OKUL } \\
\text { ORTAMI }\end{array}$ & RÖ & MY & AİLE & RÖ & MY & ÖĞRENCİ & RÖ & MY \\
\hline $\begin{array}{l}\text { Çocukların okulda mutlu } \\
\text { olmasının sağlanması }\end{array}$ & 1 & & $\begin{array}{l}\text { Öğretmenlere } \\
\text { destek verilmesi }\end{array}$ & 1 & & $\begin{array}{l}\text { Okul çevresinde } \\
\text { güvenlik } \\
\text { tedbirlerinin } \\
\text { alınması }\end{array}$ & 1 & & Veli eğitimi & 2 & 1 & $\begin{array}{lr}\text { Maddi } & \text { durumu } \\
\text { kötü } & \text { olanlara } \\
\text { destek verilmesi }\end{array}$ & 2 & \\
\hline $\begin{array}{l}\text { Çocukları okulda tutacak } \\
\text { sosyal ve sportif faaliyetler } \\
\text { yapılması }\end{array}$ & 3 & 3 & $\begin{array}{l}\text { Bu konuda sınıf } \\
\text { öğretmenlerinin } \\
\text { rolünün } \\
\text { arttırılması }\end{array}$ & 1 & & $\begin{array}{l}\text { Okulun çekici } \\
\text { hale getirilmesi }\end{array}$ & 1 & 3 & $\begin{array}{l}\text { Velilere okulun } \\
\text { öneminin } \\
\text { anlatılması }\end{array}$ & 1 & & & & \\
\hline $\begin{array}{l}\text { İlgi ve yeteneklerinin } \\
\text { önemsenerek bunlara uygun } \\
\text { faaliyetlerin yapilması }\end{array}$ & 1 & 2 & 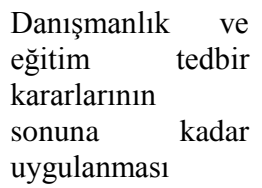 & 1 & & $\begin{array}{l}\text { Okullarda oyun } \\
\text { alanlarının } \\
\text { oluşturulması }\end{array}$ & 1 & 1 & $\begin{array}{l}\text { Birebir } \\
\text { görüşülmesi }\end{array}$ & 1 & & & & \\
\hline Turnuvalar düzenlenmesi & & 1 & $\begin{array}{l}5-6 \text { ve } 7 \text { 'lerde } \\
\text { rehberlik dersinin } \\
\text { geri getirilmesi }\end{array}$ & & 1 & $\begin{array}{l}\text { Okullarda } \\
\text { hayvanlar için } \\
\text { ortamlar } \\
\text { oluşturulmas1 }\end{array}$ & & 1 & & & & & & \\
\hline $\begin{array}{l}\text { Akademik başarısızlığın her } \\
\text { şey olmaması }\end{array}$ & & 1 & $\begin{array}{l}\text { Okulda önemli } \\
\text { olduklarının } \\
\text { hissettirilmesi }\end{array}$ & 1 & & & & & & & & & & \\
\hline $\begin{array}{l}\text { Çocukların başarıyı } \\
\text { tatmalarının sağlanması }\end{array}$ & 1 & & & & & & & & & & & & & \\
\hline
\end{tabular}


Tablo 9'da görüldüğü gibi "Öğrencilerin sürekli devamsız duruma düşmesini engellemek için hazırlanacak bir program ya da projede neler olmalıdır?" sorusuna katılımcı müdür yardımcılarından biri yanıt vermemiştir. Üç rehber öğretmen ve üç müdür yardımcısının verdikleri yanıtlar, okulun yaklaşımı, okul ortamı, aile ve öğrenci temaları altında toplanmıştır. Bu temaların alt boyutları incelendiğinde; okulun yaklaşımı temasında, çocukların okula devamlarının sağlanabilmesi için katılımcıların, en sıklıkla çocukları okulda tutacak sosyal ve sportif faaliyetler yapılması; ikinci sırada öğrencilerin ilgi ve yeteneklerinin önemsenerek bunlara uygun faaliyetler yapılması gerektiğini belirttiği görülmektedir. Ayrıca öğrencilerin mutlu olmasının sağlanması, okulda önemli olduklarının hissettirilmesi, başarıyı tatmalarının sağlanması, yeteneklerine uygun faaliyetlerin olması ve turnuvalar düzenlenmesi şeklinde doğrudan öğrenciye yönelik öneriler yer almaktadır. Bunların yanı sıra öğretmenlere de destek verilmesi ve bu konuda sınıf öğretmenlerinin rolünün arttırılması; resmi boyutta ise danışmanlık ve eğitim tedbirlerinin uygulanması gerektiği belirtilmiştir. Okul ortamı temasında, ilk sırada okulun çekici hale getirilmesi, ikinci sırada okullarda oyun alanlarının oluşturulması; aile temasında, en sıklıkla veli eğitimi olması gerektiği, ikinci sırada velilere okulun öneminin anlatılması ve birebir görüşmelerin gerekliliği yer almaktadır. Öğrenci temasında rehber öğretmenlerden ikisi, sadece ekonomik destek verilmesi gerektiğini belirtmektedir. Bu durumu rehber öğretmenlerden biri "Çalışmak için gelemeyenlere maddi destek verilmesi gerekir." (RÖ1) şeklinde ifade etmiştir.

Katılımcıların öğrencilerin sürekli devamsız duruma gelmesini engellemek için hazırlanacak programın içeriğine ilişkin öneriler Tablo 10'da verilmiştir.

Tablo 10. Katılımclların Öğrencilerin Sürekli Devamsız Duruma Gelmesini Engellemek İ̧̧in Hazırlanacak Programın İçeriğine İlişkin Önerileri

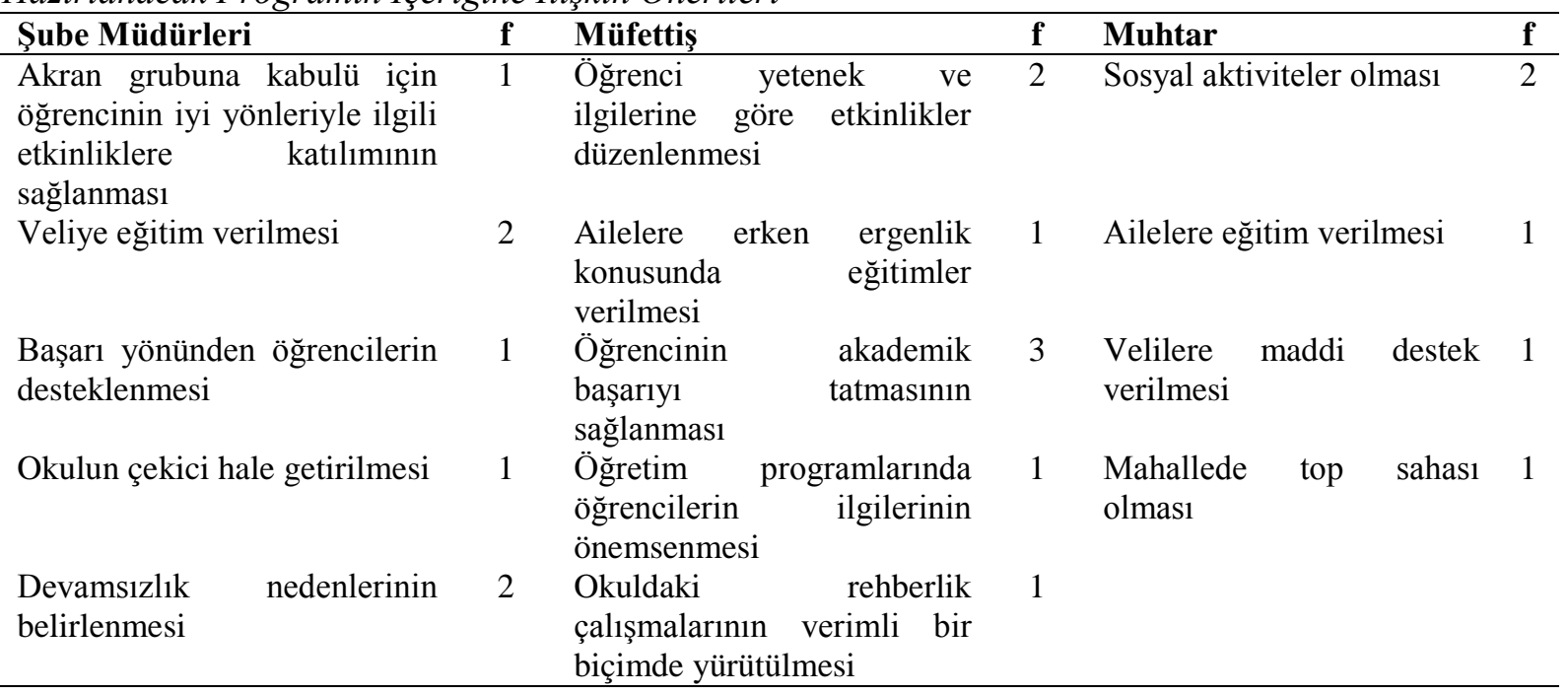

Tablo 10'da görüldüğü gibi "Öğrencilerin sürekli devamsız duruma gelmesini engellemek için hazırlanacak bir program ya da projede neler olmalıdır?" sorusuna şube müdürü, müfettiş ve muhtarların verdiği yanıtlarda, katılımcılar rehber öğretmen ve müdür yardımcılarıyla benzer gereklilikler belirtmiştir. Bunlar arasında ilk sırada öğrencilere ilgi ve yeteneklerine uygun etkinlikler düzenlenmesi, ikinci sırada ailelere eğitim verilmesi ve öğrencilerin akademik yönden desteklenmesi görülmektedir.

"Sürekli devamsı öğrencilerle ilgili olarak okul yönetimleri sizlerden neler talep etmekteler?"sorusuna muhtarlardan biri sürekli devamsız öğrencilerle ilgili olarak okul yönetimlerinin 
kendisinden bir taleplerinin olmadığını belirtmiş̧tir. Diğeri ise okul yönetimlerinin kendisinden velilerle görüşülmesi ve velinin ikna edilmesi konusunda istekte bulunduklarını şu şekilde belirtmiştir: "Genelde babalarla yaptığımız görüşmelerde ben istemez miyim çocukların okula gitmesini diye tepki veriyorlar. Veli ne kadarda cahil olsa çocuğunun okula gitmesini ister." (MUH2). Muhtar olarak sürekli devamsız öğrencilerin okula devamları için velilerle görüştüklerini, Milli Eğitim müdürlüğünden yazı geldiği durumlarda ev ziyareti yaptıklarını ve sokakta gördüğü çocuklarla ailelere haber gönderdiklerini belirtmiştir.

"Sürekli devamsız ögrencilerin aileleri ile görüşme yapıyor musunuz?" sorusuna muhtarların ikisi de ailelerle görüş̧ükleri ve ev ziyaretleri yaptıkları yanıtını vermiştir. "Ailelerin çocuklarının devamsızlıklart ile ilgili tepkileri nelerdir?" sorusuna muhtarlardan biri "Önceki muhtarlık dönemimde mahallemize göçle gelen ve $5 \mathrm{kızı} \mathrm{olan} \mathrm{bir} \mathrm{amcaya,} \mathrm{amca} \mathrm{köyünü} \mathrm{bırakıp} \mathrm{neden} \mathrm{buraya} \mathrm{geldin} \mathrm{diye}$ sorduğumda memlekette kzzlar çalışır gül gibi geçinip gidersin dediler. Bu da velilerin çocuklara bakış açısını göstermesi açısından önemli." (MUH2) şeklinde deneyimini ifade etmiştir. Yaptığınız tüm çalışmalar sonunda öğrencilerin okula devamlar sağlanabildi mi? sorusuna muhtarlardan biri, öğrencilerin okula devamlarının sağlanmasıyla ilgili bir bilgisinin olmadığını, diğeri ise önceki muhtarlık dönemlerimde okullardan talep geldiği için devamın sağlandığını ancak bu dönemde okullardan hiç talep gelmediği için bilgisinin olmadığını ifade etmiştir.

\section{Sonuçlar ve Tartışma}

Eğitim-öğretim faaliyetlerinde amaçların en üst düzeyde gerçekleşebilmesi ancak okulda öğrenim gören öğrencilerin sürece etkin katılımıyla sağlanabileceği için öğrencilerin okula devamları hayati önem taşımaktadır. Çocuğun okula devamının sağlanmasında İlköğretim ve Eğitim Kanunu'nun (1961) Okula Devam başlıklı altıncı bölümünde, öğrenci velisi, mülki amirler, ilköğretim müfettişleri ve zabıta teşkilatı yükümlü kılınmış, okula devam etmeyen öğrencilerin devamsızlık sebeplerinin okul idarelerince ve ilköğretim müfettişlerince araştırılarak devama engel durumun giderilmesi, bunun mümkün olmadığı durumlarda köylerde muhtara, diğer yerlerde mülki amirlere bilgi verilmesi ve bu makamların da gerekli tedbirler alması ifade edilmiştir. Bu nedenlerle mevcut araştırmada, öğrencilerin okula devamını engelleyen nedenleri, mevzuat çerçevesinde yapılanların yeterliliğini ve okula devam sorunu yaşayan öğrencilerin okula devamını sağlayabilecek uygulamaları mevzuatta öğrencilerin devamından sorumlu olan kişilerin görüşleri doğrultusunda belirlenmesi amaçlanmıştır. $\mathrm{Bu}$ amaçlarla yapılan araştırmada elde edilen araştırma sonuçları bulgulardaki sırayla alanyazına dayanarak tartışılmıştır.

Katılımcıların görüşlerine göre sürekli devamsız öğrenci ailelerinin sosyoekonomik düzeyiyle ilgili bulgular, ailelerin sosyoekonomik düzeyinin düşük olduğunu göstermektedir. Bu sonuç yakın geçmişte devamsızlık konusunda yapılan araştırma sonuçlarıyla da desteklenmektedir. Örneğin Hoşgörür ve Polat'ın (2015) ortaokul ögrencilerinin okula devamsızlık nedenlerini belirlemek amaciyla 20 gün ve üzerinde devamsızlı yapan öğrenci sayısının en fazla olduğu bir okulda okula devamsızlık yapan 27 gönüllü öğrenciyle yaptığı araştırmada, ailelerin sosyoekonomik düzeyinin düşük olduğu ve bu durumun devamsızlığı doğrudan etkilediği; Adıgüzel'in (2013) kız çocuklarının okullulaşmalarının önündeki engelleri belirlemek amacıyla yaptığı araştırmada; okula gidememe nedenleri arasında ilk üç sırada sosyo-kültürel (\%15.8), ailevi (\%11.8) ve ekonomik (\%10) nedenler olduğu; Köse'nin (2014:5) okul terki ve devamsızlık sorunlarını yönetici, öğretmen, veli ve öğrenci katılımıyla belirlediği araştırmada devamsız öğrencilerin ailelerinin maddi durumlarının kötü olduğu; Nar'ın (2008) Dilovası'nda göçün eğitime ve eğitim yönetimine etkisini belirlemek amacıyla yaptığı araştırmada, öğretmenler göçle gelen ailelerin ekonomik sorunlar yaşadığı, bu nedenle çocuklarını 
çalıştırdıkları ve çocukların okula bu nedenle devamsızlık yaptıkları; Aküzüm, Yavaş, Tan ve Uçar'ın (2015) ilköğretim kurumu öğrencilerinin devamsızlık ve okul terki kaynağında ailelerin ekonomik zorluklarının olduğu; Özbaş'ın (2010) ilköğretim okullarında öğrenci devamsızlığının nedenleri ve öğrencilerin okula tam devamlarının sağlanması için ilgililerin yapması gerekenleri belirlemek amacıyla yaptığı araştırma sonuçlarına göre öğrencilerin devamsızlı yapma nedenlerinin ailelerin çocuklarının okul ihtiyaçlarını karşılayamaması olduğu belirlenmiştir. Hem alanyazındaki sonuçlar hem de mevcut araştırma sonuçları sürekli devamsız olan öğrencilerin ailelerinin sosyoekonomik düzeyinin düşük olduğunu ortaya koymaktadır. Bu sonuçlar, okula devamsızlık konusunda ilk sıradaki nedenlerin arasında sosyoekonomik düzeyin düşük olmasını göstermektedir. Oysa 1961 tarihi ve 222 sayılı İlköğretim ve Eğitim Kanununun 6. Bölümünün 53. maddesinde (Değiş̧ik: 12/10/1983 2917/7md.) "Okula devam etmeyen öğrencilerin devamsızlık sebepleri okul idarelerince ve ilköğretim müfettişlerince araştırılarak devama engel olan maddi ve manevi sebeplerin giderilmesine çalışılır." denmektedir. Bu madde, okullarda tam olarak uygulamaya geçirilmiş olabilse, aslında bu konudaki bilimsel çalışmalardan çok daha önce okul idarecileri ve müfettişler tarafından devamsızlığın nedenlerinin belirlenmesine yönelik tespit çalışmaları yapılarak devama engel olan maddi ve manevi nedenlerin giderilmesi için somut çözümler getirilmiş olacaktı. Ayrıca bu konuyla ilgili aynı maddenin devamında "Okul idareleriyle muhtar ve mülki amirlerin bu vazifeleri devamsız öğrenciler hakkındaki kovuşturmanın her safhasında devam eder." denilerek, ilgili yetkililerin sorumluluklarının sadece sorunun tespiti ve çözümüyle bitmediği, durumu takip etmeleri gerektiği de belirtilmektedir.

Sürekli devamsız öğrencilerin ailelerinin öğrenim düzeyine ilişkin araştırma bulguları, özellikle de annelerin okuryazar olmadığı ve babaların ise ilk ve ortaokul mezunu olduğunu göstermektedir. Ailenin özelliklerinin okul başarısında tek başına çok önemli gösterge olduğu ileri sürülmektedir (Rumburger 2001:14). Uganda'da ilkokulu birakmanın sosyoekonomik göstergelerinin belirlenmesi amacıyla yapılan araştırmada ailenin öğrenim düzeyinin çocukların okula devamını etkilediği belirlenmiştir (Okumu, Nakajjo ve Isoke, 2008). Alanyazın incelendiğinde ülkemizde okul devamsızlığı konusunda yapılan araştırmalardan sadece Hoşgörür ve Polat (2015)'ın yaptığ1 araştırmada 20 gün ve üzerinde devamsızlık yapan 27 gönüllü öğrencinin annelerinin \%51.9'unun annesinin okuryazar olmadığı, \%40.7'sinin ilkokul mezunu olduğu belirlenmiştir. Bu sonuçlar özellikle de annelerin ögrenim düzeyinin düşüklüğ̈̈yle okula devamsızlık arasında bir ilişki olduğunu göstermektedir. Anne öğrenim düzeyinin düşük olması, beraberinde annenin çocuğunun öğrenimine devamının yaşamsal öneminin farkında olmamasına neden olmakta bu da çocuğuna gereken desteği verememesine de yol açmaktadır. Bu farkındalığın artırılması da aile eğitimleriyle sağlanabilir.

Sürekli devamsız öğrencilerin okula devam etmesi için okullarda yapılanlara yönelik araştırma bulguları, en sıklıkla devamsızlık mektubu gönderildiği ve ev ziyareti yapıldığını göstermektedir. Devamsızlık mektubu, ortaokul öğrencilerinin ergenlik dönemine girdiği ve akran ilişkilerinin en yoğun etkisinin olduğu bir dönemde, özellikle de sabah evinden okula gitmek üzere çıkan öğrencilerden okula gitmeyen öğrencilerin ailelerinin erken dönemde durumdan haberdar olmaları bakımından büyük önem taşımaktadır. Sürekli devamsız öğrencilerinin evlerinin ziyaret edilmesi, öğrencilerin nasıl bir ortamda yaşadıklarının yakından görülmesi ve ailesiyle birebir iletişim kurulması, öğrencinin ailesiyle ilgili sorunların/güçlüklerin yetkililerle paylaşılması ve erken dönemde önlemlerin alınabilmesi ve destek verilebilmesi için bir gereksinim olarak görülmektedir. Alanyazında ülkemizde devamsızlık konusunda yapılan araştırmalarda devamsızlığın önlenmesine yönelik katılımcıların önerileri belirlenmiş ancak okul, mahalle, ilçe ve il düzeyinde yetkililerin yaptıklarını ortaya koyan araştırma sonucu bulunmamaktadır. 
Araştırma bulguları, öğrencilerin sürekli devamsız duruma gelmelerine en sıklıkla öğrencilerin derslerde başarısız olmaları ve arkadaş grubunun neden olduğunu göstermektedir. Rumburger'in (2001:10) öğrencilerin okula devam etmeme nedenleri ve bunu önlemek için neler yapılabileceğini belirlemek amacıyla yaptı̆̆ 1 araştırmada okulda devamsızlığ etkileyen faktörleri dört grupta ele almıştır. Bunlar, aile, okul, toplum ve akranlardır. Aynı araştırmada öğrencilerin okula başladıkları günden itibaren derslerdeki başarılarının okula devamlarında doğrudan etkili olduğu ve bu durumun öğrencinin okula dair tutumlarını da etkilediği belirlenmiştir. Bunun yanı sıra okul sonrasında öğrencinin katılacağı faaliyet veya programlar ile yeterli oyun alanlarının olmamasının da okul devamsızlığı konusunda akranların olumsuz etkilerini artırdığı belirlenmiştir. Okullardaki olanakların yeterli olmamasının öğrencilerin sürekli devamsız duruma gelme nedenlerinden biri olduğu Aküzüm, Yavaş, Tan ve Uçar'ın (2015) yaptığı araştırmada da ortaya çıkmıştır. Ayrıca Sütçü (2015), düşük başarı göstermeleri ve ders etkinliklerine katılımın az olması nedeniyle akademik konularda zorluk yaşayan öğrencilerin okulu bıraktıklarını yani başarı düzeyi düştükçe okulu bırakma riskinin arttığını belirlemiştir.

Wilson, Tanner-Smith, Lipsey, Steinka-Fry ve Morrison'un (2011) okulu bırakmayı önleme ve müdahale programlarını değerlendirdiği araştırmada, göçle gelen sosyoekonomik düzeyi düşük olan ailelerin çocuklarının okula devamsızlık yönünden risk altında olan çocuklar olduğu bildirilmektedir. Mevcut araştırmada, öğrencilerin sürekli devamsız duruma gelme nedenleri arasında ikinci sırada velilerin çocuklarını çalıştırması ve üçüncü sırada da öğrencilerin maddi imkansızlıklarının olması da bu sonucu doğrulamaktadır. Ayrıca Baruah ve Goswami (2012), Okuşluk Çapur (2006), Nar (2008), Aküzüm, Yavaş, Tan ve Uçar (2015), Özbaş (2010), Adıgüzel (2013), Gömleksiz ve Özdaş (2013), Hoşgörür ve Polat'ın (2015) yaptığı araştırmalarda da ailelerin maddi yetersizliklerinin okul devamsızlığına neden olan faktörler arasında olduğu belirlenmiştir.

Okula devamın sağlanmasında tarafların katılımının olduğunun belirtilmesi konudan sorumlu yetkililer arasında işbirliğinin olduğu şeklinde değerlendirilebilir. Diğer taraftan araştırma bulgularına göre, yapılan görüşmeler sonunda öğrencilerin okula devamlarının sağlanmasında en çok aile ziyaretlerinin etkili olduğu belirlenmiştir. Ardışık Devamsızlıkta Aşamalı Eylem Planları'nın (İlköğretim Okulları İçin Aşamalı Devamsızlık Yönetimi ve Uygulama Kılavuzu, 2011) "Genel Nedenlere Bağlı Ardışık Özürsüz Devamsızlıkta Aşamalı Eylem Planı'na (AEP1a)"” göre öğrenci iki gün üst üste devamsızlık yaptığında "ardışık özürsüz devamsızlık" yapmış sayıldığ1 ve çocuğun okula gelmediği durumlarda, velinin okula davet edilmesi, ancak veli gelmez veya veliye ulaşılamaz ise "Genel Nedenlere Bağlı Ardışık Özürsüz Devamsızlık Eylem Planını'n (AEP1a)" uygulanmasını, çocuğun okula gelmediği 3 . günde velisiyle görüşülmesi ve ulaşılamazsa ev ziyareti yapılması belirtilmektedir. Muş İl Milli Eğitim Müdürlügünün okullara gönderdiği 8 Ekim 2015 tarih ve 32026198-200-E. 10080864 sayılı "Ev Ziyaretleri ve Devamsızlık Takibi” konulu resmi yazıda ise "2015-2016 eğitim öğretim yılında öğrencilerin okula devamlarının sağlanması ve verimliliklerinin artırılması amaciyla, okulunuz idareci ve öğretmenlerinden oluşturulacak komisyonca yapılacak öğrenci ev ziyareti çalışmalarında, oluşturulacak olan komisyonda okul rehber öğretmeni, ortaokullarda her sınıfin sorumlu şube rehber öğretmeni ve ilkokullarda sınıf öğretmeninin görevlendirilmesi, komisyonların devamsız öğrenciler ile ilgili ev ziyareti yaparak ziyaret esnasında Ek-1 formunu doldurmaları ve velilere 222 sayılı Eğitim Öğretim Kanununun devamla ilgili maddeleri ile cezai müeyyidelerin anlatılması..." devamsız öğrencilere yapılacak ev ziyaretlerinin nasıl yapılacağı açıklanmıştır. Hem mevcut araştırma sonuçları, hem ADEY'deki işleyiş, hem de ev ziyaretleri ve devamsızlık takibi konusunda il milli eğitim düzeyinde yapılan çalışmalar, ev ziyaretlerinin çocuğun okula devamsızlık yaptı̆̆ duruma müdahale edilmesi anlamına gelir. Oysa devamsızlıklar olmadan her yıl eğitim-öğretim 
başlamadan önce bir önceki yılın e-okul kayıtları incelenerek devamsızlık yönünden risk grubunda olan öğrenciler, şube öğretmeni, rehber öğretmen ve ilgili okul yöneticisinin işbirliğiyle belirlenerek mahalle, belediye ve ilçe milli eğitim müdürlükleriyle öğrencilerin sorunlarının çözümü ve gereksinimlerinin giderilmesi için girişimlerde bulunulabilir.

Araştırma bulguları, öğrencilerin okula devamlarının sağlanabilmesi için mevzuat çerçevesinde yapılanların yeterli olmadığını göstermektedir. Mevzuat çerçevesinde yapılanları yeterli görmeyen katılımcılar ilk sırada cezai yaptırımların uygulanmasını belirtmiştir. İlköğretim Okulları İçin Aşamalı Devamsızlık Yönetimi Uygulama Kılavuzu'nun (MEB, 2011:32) "Yasal Yaptırım" bölümünde yasal sürecin başlatılması için dikkat edilmesi gerekenler şu şekilde sıralanmıştır: a.Çocuğun ilköğretime devamını sağlamak için veliye ve çocuğa dönük yaptığınız her tür çalışmanın (Ev ziyareti formu, Veli görüşme tutanağı, Okula devam sözleşmesi, mektup, Risk ihtiyaç analizi sonuçları, Devamsızlık odaklı müdahale raporları vb.) dokümanını arşivleyin. b.Veliye gönderdiğiniz Okula Devam Sözleşmesini içeren mektubu iadeli taahhütlü gönderiniz (7201 Sayılı Tebligat Kanunu). Alındı belgesini çocuğun takip dosyasına ekleyiniz. c.Çocuğun okula devamını sağlamaya dönük yapılan çalışmalardan (ADEY) sonra çocuk hala devamsızlık yapıyorsa, köylerde muhtarlığa, diğer yerlerde mülki idare amirine yasal sürecin başlatılması için yazıyla bildiriniz (222 Sayılı İlköğretim ve Eğitim Kanunu ve 2009/46 Sayılı MEB Genelgesi). d.İdari para cezasına rağmen çocuğun ilköğretime devamı sağlanamadıysa, savcılığa suç duyurusunda bulununuz (5395 Sayılı Çocuk Koruma Kanunu). e.Aynı zamanda durumu çocuğun içinde bulunduğu risk halinin araştırılması ve gerektiğinde koruyucu ve destekleyici tedbirler ile çocuğun korunması ve eğitime devamının sağlanması için durumu sosyal hizmetler il müdürlüğüne bildiriniz (2828 Sayılı SHÇEK Kanunu). Bu çalışmaların yürütülmesinden de okul yönetimi, il ve ilçe milli eğitim müdürlüklerinin sorumlu olduğu belirtilmiştir.

Araştırma bulguları ve katılımcıların beyanları, mevzuat açısından değerlendirildiğinde, öğrencilerin okula devamının sağlanması konusunda Aşamalı Devamsızlık Yönetimi (2011) konusunda yasal yaptırım sürecinde yapılması gerekenlerden sadece devamsızlığı bildirmek amacıyla mektup yazıldığ ve ev ziyaretleri yapıldığı anlaşılmaktadır. Diğer taraftan "risk, ihtiyaç analizi sonuçları" ve "devamsızlık odaklı müdahale programlarının" ise uygulamaya geçirilmediği; idari para cezasının işleme konulmadığ 1 ve çocuğun içinde bulunduğu risk halinin araştırılması ve gerektiğinde koruyucu ve destekleyici tedbirler ile çocuğun korunması ve eğitime devamının sağlanmasına dair herhangi bir çalışma yapılmadığı görülmektedir. Bu yönüyle araştırmaya katılan müfettişlerden birinin "mevzuatı yeterli olduğu" ve "Ancak uygulayıcıların mevzuatı verimli biçimde uygulaması önemli. Ayrıca ilçe milli eğitim müdürlükleri ve müfettişler okulların devamsızlıkla ilgili iş ve işlemlerini daha düzenli kontrol etmelidir. Ayrıca para cezasının uygulanması da etkili olabilir.” (MÜF:1) düşüncesi ve bir müdür yardımcısının para cezasının uygulanmadığına dair beyanı doğrulanmaktadır. Başka bir ifadeyle aslında mevzuatta okula devamsızlı̆̆ın erken dönemde belirlenmesi ve azaltılmasına ilişkin adım adım yapılacaklar net bir şekilde ifade edilirken, sürecin işleyişindeki aksaklıkların kaynağında bu çalışmaların yürütülmesinden sorumlu okul yönetimi, il ve ilçe milli eğitim müdürlükleri arasında mevzuatın uygulanması konusunda yeterli eşgüdümün sağlanamadığı görülmektedir.

Öğrencilerin sürekli devamsız duruma düşmesini engellemek için hazırlanacak bir program ya da projede araştırma bulgularına göre okulun yaklaşımı, okul ortamı, aile ve öğrenci temaları bulunmaktadır. Okulun yaklaşımı temasında, çocukların okula devamlarının sağlanabilmesi için katılımcılar en sıklıkla çocukları okulda tutacak sosyal ve sportif faaliyetler ve ikinci sırada öğrencilerin ilgi ve yeteneklerinin önemsenerek bunlara uygun faaliyetler yapılması gerektiği belirtilmiştir. Şanlı, Altun ve Tan'ın (2015) araştırmasına katılan öğrencilerin de okulun sadece ders 
ortamı olmaktan çıkartılıp yaşanabilir, daha fazla sosyal etkinliklerin yapıldığı bir ortam haline getirilmesi gerektiğini istedikleri belirlenmiştir. Rumberger (2001), çocukların okul saatlerinde sosyal faaliyetlere katılımının hem akranları ve yetişkinlerle ilişkilerini geliştireceği hem de okula dair tutumlarını olumlu yönde etkileyeceğini belirtmektedir. Ayrıca Devamsızlık ve Okulu Terk Riski Durum Saptaması ve İhtiyaç Analizi Taslak Raporunda (MEB, 2009:93) öğrencilerin \%85.8'inin ders dışındaki okul aktivitelerine katılmayı sevdikleri belirlenmiştir. Bu sonuçlar, okullarda devamın sağlanması konusunda öğrencilerin ilgi, yetenek ve gereksinimlerini karşılayacak şekilde sosyal ve sportif faaliyetlerin düzenlenmesinin bir gereksinim olduğunu göstermektedir.

Okul ortamı temasında, okulun çekici hale getirilmesi ve okullarda oyun alanlarının oluşturulması istenmiştir. Araştırma sonuçları okulların fiziki koşullarının öğrencilerin rahat edebilecekleri şekilde düzenlenmesi (Gömleksiz ve Özdaş, 2013) ve okulların eğlenceli yerler olmasının okula devamın sağlanmasında etkili bir unsur olduğunu göstermektedir (Köse, 2014; Hoşgörür ve Polat, 2015). Şanl1, Altun ve Tan'a (2015) göre okulların en önemli varlık nedenleri öğrencilerin eğitim gereksinimlerini karşılamak ve onlara güçlü oldukları alanlarda gelişme olanakları sunmaktır. Ancak araştırmaya katılanların devamsızlığı azaltmak amacıyla uygulanacak bir program veya projede olması gerekenler arasında belirttikleri unsurlardan "okulun çekici hale getirilmesi, okullarda oyun alanlarının oluşturulması, okullarda hayvanlar için ortamlar oluşturulması, çocukların okulda mutlu olmasının sağlanması, çocukları okulda tutacak sosyal ve sportif faaliyetler yapılması, yeteneklerine uygun faaliyetler olması, çocukların başarıyı tatmalarının sağlanması, akademik başarısızlığın her şey olmaması" şeklindeki düşünceler, aslında okulların, en önemli varlık nedenleri olan öğrenci gereksinimlerinin karşılanması ve güçlü oldukları alanlarda gelişme olanakları sunulması konusunda yeterli olmadıklarını göstermektedir.

Araştırma bulgularında aile temasında, en sıklıkla veli eğitimi olması, ikinci sırada velilere okulun öneminin anlatılması ve birebir görüşmelerin gerekliliği yer almaktadır. Baruah ve Goswami (2012), ebeveynlere rehberlik yapacak eğitimlerinin olmamasının ilkokul düzeyinde okul terkini etkileyen en etkili faktörlerden biri olduğunu belirlemiştir. Mevcut araştırma sonuçları ve alanyazında öğrencilerin sürekli devamsız duruma düşmesini engellemek için yapılması gerekenler arasında ilk sıralarda ailelere eğitim verilmesi ve eğitimin öneminin anlatılması (Özbaş, 2010; Gömleksiz ve Özdaş, 2013; Haberli ve Güvenç, 2012) yer almaktadır. 222 sayılı İlköğretim ve Eğitim Kanununun (1961) altıncı bölümünde "Okula devam" başlı̆̆ altındaki 52. madde ile "Her öğrenci velisi yahut vasisi veya aile başkanı çocuğunun mecburi ilköğretim kurumuna muntazaman devamını sağlamakla ve özrü yüzünden okula gidemeyen çocuğun durumunu en geç üç gün içinde okul idaresine bildirmekle yükümlüdür." denerek öğrencinin okula devamını sağlamaktan sorumlu olan kişinin öğrenci velisi veya vasisi olduğu belirtilmektedir. Bu durumda, okula devamsızlık yapan çocukların ailelerinin büyük çoğunluğunun öğrenim ve gelir düzeyinin düşük olduğu göz önünde bulundurulduğunda, başl1 başına ailelere ilişkin bu özellik bile tek başına ailenin eğitime duyduğu gereksinimi ortaya koymaktadır. Okula devamın sağlanmasında aile eğitiminin önemini ortaya koyan araştırmalardan birinde (Mercan Uzun ve Bütün, 2015), okula devam etmeyen Roman öğrencilerin ailelerine ceza verilmesinin onların eğitime bakış açısı veya beklentilerinde bir değişmeye yol açmayacağı gibi ailelerin okula yönelik olumsuz bakmalarına da neden olacağı ve bu durumun sorunun çözümünü sağlayamayacağı belirtilmektedir. Bu nedenlerle okulun birey ve topluma kazandırabileceklerinin Roman ailelere doğru bir şekilde anlatılması gerektiği belirtilmektedir.

Öğrenci temasında katılımcıların belirttiği ekonomik destek verilmesi önceki araştırma sonuçlarıyla (Köse, 2014; Özbaş, 2010) örtüşmektedir. Bu yönüyle öğrenciler desteklendiğinde, okul 
devamsızlığındaki risk faktörleri arasında görülen düşük sosyoekonomik statünün etkisi azaltılabilir (Veenstra, Linderberg, Tinga ve Ormel, 2010'dan aktaran Şanlı Kula ve Yıldız, 2015).

Araştırma bulguları arasında okula devamın sağlanması amacıyla uygulanacak bir program veya projede akademik destek verilmesi ifade edilmiştir. Bu sonuç, sürekli devamsızlığın nedenleri arasında ilk sırada yer alan öğrencilerin okulda başarısız olmaları bulgusunu da doğrulamaktadır. Mevcut araştırma sonuçları, akademik başarısızlık nedeniyle sürekli devamsız konumuna gelen bu öğrencilerin bu konuda en çok destek alacakları ailelerinin ne bu desteği verebilecek öğrenim düzeyinde ne de dışarıdan destek almasını sağlayabilecek gelir düzeyinde olmadığını göstermektedir. Bu noktada, öğrencilerin okul ders saatleri dışında, yine okullarında ücretsiz olarak akademik yönden desteklenmesiyle başarısızlık durumları da algıları da değiştirilebilir. Millî Eğitim Bakanlığı Örgün ve Yaygın Eğitimi Destekleme ve Yetiştirme Kursları Yönergesinde Değişiklik Yapılmasına Dair Yönergesinin (MEB, 2014) 10.maddesinde "Kurslar, öğrenci/kursiyer ve velilerden gelen istek üzerine, örgün ve yaygın eğitim kurumlarında öğrenim görmekte olan öğrenciler ile ortaöğretim kurumlarından mezun kursiyerler için belirlenen kurs merkezlerinde, Bakanlıkça ilan edilen örgün eğitim müfredatındaki derslerle sınırlı olarak açılır.” denilmektedir. Aslında bu düzenlemeden ilk sırada yararlanacaklar arasında okula devam yönünden risk altındaki çocuklar yer alabilir. $\mathrm{Bu}$ kapsamda şube öğretmenlerinin velilerle okulun başlangıcında yapacağı bilgilendirme toplantılarıyla, velilerin kurslardan haberdar edilmesi, çocukların kurslara katılımı konusunda veli desteğinin alınması sağlanabilir. Böylelikle kurslarla öğrencilerin akademik başarılarının yükselmesiyle hem okula dair tutumlarının değişmesi sağlanabilir hem de başarısızlık nedeniyle akranlarının zorbalığına uğraması önlenebilir.

Sonuç olarak insanın temel haklarından biri olan eğitim, Dünya Bankası (1993) tarafından insan gelişimi ve ekonomik büyümenin katalizörü olarak (Akt. Okumu, Nakajjo ve Isoke, 2008) araştırmacılar tarafından sosyoekonomik gelişme ve yaşam kalitesi için bir gereksinim olarak görülmektedir (King, Dewey, ve Borish, 2015). Diğer taraftan araştırma sonuçları, sosyoekonomik statünün göstergesi olan ailenin öğrenim ve gelir düzeyinin, okul başarısı ve okula devamın en güçlü belirleyicisi olduğunu göstermektedir (Rumburger, 2001:14). Dokuzuncu Millî Eğitim Şurasında (1974), "Temel eğitim döneminde çocuğu kendi yaş grubu içinde arkadaşları ile birlikte yetiştirme değişmez bir hedeftir; öğretmen, programlar, öğrenci akışını düzenleyen kurallar gibi unsurların hepsi değişkendir ve çocuğu yetiştirme görevinde bir araçtır.” denilmektedir (Yetiştirici Sınıf Öğretim Programı Yönerge ve Uygulama Kılavuzu, 2010:3). Bundan yaklaşık olarak yarım asır önce çocuğun temel eğitimine devamını sağlamak için böylesine çok yönlü bir yaklaşım söz konusuyken, bugün hala okula devamsızlığın önlenmesinin yollarının aranması, bu konuda yol kat edilemediğini göstermektedir. Her şeyden önce yaşamdaki başarının belirleyicisi olarak görülen erken çocukluk eğitiminin ülkemizde zorunlu eğitim basamağında olmaması, okul devamsızlığını azaltmaya yönelik çabaların kesin çözüm getirmeyeceğinin bir başka göstergesi olduğu düşünülmektedir. Öyle ki OECD (2013) raporlarına göre, okulöncesi eğitim almış olmak ve öğrencinin 15 yaşındaki akademik performansı arasında sosyoekonomik durumdan bağımsız güçlü bir ilişki vardır (Eğitim İzleme Raporu, 2015:45). Erken dönemde okula devam konusunda ailelerin ekonomik durumlarının iyileştirilmesinin düşük bir olasılık olduğu düşünüldüğünde, en kısa zamanda yapılabilecek ve kalıc1 etkileri olacak adımlardan biri erken çocukluk eğitiminin zorunlu eğitim kapsamına alınmasıdır. Bir başkası ülkemizde uzun yıllardır uygulanan Anne Destek Programı (Metindoğan Wise, 2012) ve Baba Destek Programı (Atmaca Koçak, 2004) gibi programların yanı sıra bir süredir Milli Eğitim Bakanlığı bünyesinde yürütülen 12-18 Yaş Aile Eğitimi Kurs Programı (MEB, 2014) gibi programların hedef kitleye ulaştırılması, ailelerin öğrenim düzeylerinin geliştirilmesi için okuryazarlık programları uygulamaya geçirilebilir. Ayrıca öğrencinin kendisini okula ait hissetmesi, akranları ve 
öğretmenleriyle iyi ilişkiler kurmasını (Cabus, 2015) sağlayarak doğrudan devamsızlık yaptığı belirlenen öğrencilerin gereksinimleri ve sorunlarının giderilmesine dayalı programların uygulanması ve izleme çalışmalarının sürdürülmesi, öğrencilerin öğrenimlerine devam etmelerinde etkili olacaktır.

\section{Kaynaklar}

Adıgüzel, A. (2013). Kız çocuklarının okullulaşma engelleri ve çözüm önerileri (Şanlıurfa Örneği). EKEV Akademi Dergisi, 17(56), 325-344.

Aküzüm, C., Yavaş, T., Tan, Ç., \& Uçar, M.B. (2015). İlköğretim kurumu öğrencilerinin devamsızlık ve okul terki nedenleri. Uşak üniversitesi Sosyal Bilimler Dergisi, 8, 167-192.

Atmaca Koçak, A. (2004). Baba Destek Programı Değerlendirme raporu. http://www.acev.org/docs/raporlar/07 baba destek programi degerlendirme raporu.pdf?sfvrsn $=2$ 12.02.2016.

Baruah, S.R. \& Goswami, U. (2012). Factors influencing school dropouts at the primary level. International Journal of Farm Sciences 2(1), 141-144.

Bilgin, N. (2006). Sosyal Bilimlerde içerik analizi: teknikler ve örnek çalışmalar. (2. Baskı). Ankara: Siyasal

Kitabevi.

Binbaşığlu, C. (1995). Türkiye'de eğitim bilimleri tarihi, İstanbul: MEB Yayınları.

Cabus, S.J. (2015). Does Enhanced Student Commitment Reduce School Dropout? Evidence from Two Major Dropout Regions in the Netherlands. Regional Studies, 49(4), 599-614.

Demirel, Ö. (2004). Eğitimde program geliştirme (7. Baskı), Ankara: Pegema Yayıncılık.

Devamsızlık ve Okulu Terk Riski Durum Saptaması ve İhtiyaç Analizi Taslak Raporu http://ysop.meb.gov.tr/dosyalar/adey/ihtiyacanaliziraporu.pdf

Elo, S. \& Kyngas, H. (2008). The qualitative content analysis process. Journal of Advanced Nursing, 62(1), 107-115. doi: 10.1111/j.1365-2648.2007.04569.x

ERG (2015). Eğitim İzleme 2014-2015.

http://erg.sabanciuniv.edu/sites/erg.sabanciuniv.edu/files/EIR2014 04.09.15.WEB.pdf $\underline{05.11 .2015}$

Gömleksiz, M. \& Özdaş, F. (2013). Öğrenci devamsızlıklarının eğitim denetmenlerinin görüşlerine göre değerlendirilmesi. Elektronik Sosyal Bilimler Dergisi 12(47), 106-124.

Haberli, M. \& Güvenç, M.F. (2012). Ortaokul öğrencilerinin cinsiyet değişkeni bağlamında devamsızl1k nedenleri. Insan ve Toplum Bilimleri Dergisi, 1(4), 149-166.

Hoşgörür, V. \& Polat, M. (2015). Ortaokul öğrencilerinin okula devamsızlık nedenleri (Söke ilçesi örneği). Muğla Sıtkı Koçman Üniversitesi (MSKU) Eğitim Fakültesi Dergisi, 2(1), 25-42.

İlköğretim ve Eğitim Kanunu (1961). http://mevzuat.meb.gov.tr/html/24.html. 29.02.2016

İlköğretimde Öğrenci Devamsızlığının Azaltılması (2015). http://www.egitimreformugirisimi.org. 15.08.2016

King, N., Dewey, C., \& Borish, D. (2015). Determinants of Primary School NonEnrollment and Absenteeism: Results from a Retrospective, Convergent Mixed Methods, Cohort Study in Rural Western Kenya. PLoS One, 10(9), http://www.ncbi.nlm.nih.gov/pubmed/26371885 
Köse, N. (2014). Acarlar beldesinde okul terkleri ve devamsızlık sorunu (Yüksek Lisans Tezi, Adnan Menderes Üniversitesi Sosyal Bilimler Enstitüsü Eğitim Bilimleri Anabilim Dalı, Aydın). www.akademik.adu.edu.tr/enstitu/sosyal/.../Egitim_Bilimleri.docx adresinden edinilmiştir.

MEB (2010). Yetiştirici Sınıf Öğretim Programı Yönerge ve Uygulama Kılavuzu. http://ysop.meb.gov.tr/dosyalar/ysop/Yonerge\%20ve\%20Kilavuz.pdf 12.02.2016

MEB (2011). İlköğretim Okulları İçin Aşamalı Devamsızlık Yönetimi (ADEY). Hazırlayanlar $\begin{array}{lllll}\text { Kültegin Ögel } \quad \& \quad \text { Gülşah Karadayı. Ankara. } & 12.02 .2016 .\end{array}$ http://www.meb.gov.tr/duyurular/duyurular2011/ADEY/ADEY_KILAVUZ_07_Eylul.pdf

MEB (2014). Millî Eğitim Bakanlığı Örgün ve Yaygın Eğitimi Destekleme ve Yetiştirme Kursları Yönergesinde Değişiklik Yapılmasına Dair http://hbogm.meb.gov.tr/meb iys dosyalar/2015 11/02041613 desteklemeveyetitirmekursudeii klikmetni.pdf 12.02.2015

MEB (2014). Aile Eğitimi Kurs Programı (0-18 Yaş Çocuğu Olan Ailelere) 12-18 Yaş Aile Eğitimi Kurs Programı. Ankara. http://aileegitimi.meb.gov.tr/upload/12-18 AEP Program renkli.pdf 12.02.2016

Mercan Uzun, E. \& Bütün, E. (2015). Roman çocukların okula devamsızlık nedenleri ve bu durumun çocuklar üzerindeki etkileri. Hacettepe Üniversitesi Sağlık Bilimleri Fakültesi Dergisi, 1(2), 315-328.

Metindoğan Wise, A. (2012). Anne Destek Programı (ADP) Eğitimlerinin Etki Değerlendirmesi Araştırması. AÇEV. http://www.acev.org/docs/raporlar/adp-etki-degerlendirme.pdf?sfvrsn=2 12.02.2016

Muş İl Milli Eğitim Müdürlüğü (2015). Ev Ziyaretleri ve Devamsızlı Takibi. http://mus.meb.gov.tr/meb_iys_dosyalar/2015_10/09083031_evziyaretlerivedevamszlktakibi.pd $\underline{\mathrm{f} 12.02 .2016 .}$.

Nar, B. (2008). Göçün eğitime ve eğitim yönetimine etkisi (Dilovası Örneği). (Yüksek Lisans Tezi, Sakarya Üniversitesi Sosyal Bilimler Enstitüsü Eğitim Bilimleri Anabilim Dalı, Sakarya). https://www.academia.edu/ adresinden edinilmiştir.

Okumu, I.M., Nakajjo, A., \& Isoke, D. (2008). Socioeconomic determinants of primary school dropout: the logistic model analysis. Economic Policy Research Center, Makerere University. . https://mpra.ub.uni-muenchen.de/7851/1/MPRA_paper_7851.pdf 11.02.2016

Okuşluk Çapur, Ç. (2006). Çalışan ilköğretim öğrencilerinin eğitim beklentileri. (Yüksek Lisans Tezi, Çukurova Üniversitesi Sosyal Bilimler Enstitüsü Eğitim Bilimleri Anabilim Dalı, Adana). http://library.cu.edu.tr/tezler/5864.pdf adresinden edinilmiştir.

Özbaş, M. (2010). İlköğretim okullarında öğrenci devamsızlığının nedenleri. Eğitim ve Bilim, 35(156), $32-44$.

Rumberger, Russell W., (2001). Why students drop out of school and what can be done. University of California, Santa Barbara. https://escholarship.org/uc/item/58p2c3wp 07.08.2015

Sütçü, Z., (2015). Okul terk riski ölçeğinin geliştirilmesi. (Yüksek Lisans Tezi, Gazi Üniversitesi Eğitim Bilimleri Enstitüsü Eğitim Bilimleri Anabilim Dalı, Ankara). http://www.acikarsiv.gazi.edu.tr/index.php?SayfaNo=4\&secim=5\&menu=2\&txtAbstract=ortala ma\& adresinden edinilmiştir. 
Şanlı Kula, K. \& Yıldız, M. (2014). İlköğretim okulu 7. ve 8. sınıf öğrencilerinin devamsızlık nedenleri ile cinsiyet ve sınıf düzeyi arasındaki ilişkinin incelenmesi. Hacettepe Üniversitesi Eğitim Fakültesi Dergisi, 29(1), 251-266.

Şanlı, Ö., Altun, M., \& Tan, Ç. (2015). Okula devamsızlık yapan öğrencilerin devamsızlık sebeplerinin öğrenci görüşlerine göre değerlendirilmesi. Elektronik Sosyal Bilimler Dergisi 14(55), 161-177.

Yıldırım, A. ve Şimşek, H. (2008). Sosyal bilimlerde nitel araştırma yöntemleri (6. Baskı). Ankara: Seçkin Yayınları.

Yıldız, M. (2011). İlköğretim okulu öğrencilerinin devamsızlık sebeplerinin araştırılması, (Yüksek Lisans tezi, Ahi Evran Üniversitesi Fen Bilimleri Enstitüsü, Kırşehir.) http://www.tez.yok.gov.tr adresinden alınmıştır.

\section{Extended Summary}

Purpose

In the Primary School Program (1948, s.6), educational institutions, which are needed for carrying out learning process systematically (Demirel, 2004, 221), are defined as 'a community where students, teachers and administrators as well as families are involved; a real life stage during which they are attached to each other via the emotions of cooperation, solidarity and responsibility and share each other's joys, sorrows, experiences and knowledge' (Binbaşığlu, 1995). In this context, in order to carry out the educational process carried out with the aim of achieving individual and social development in line with its goal, it is especially important that students, who are in the center of the process, should attend school. Lan and Lanthier (2003) stated that school dropout takes place as a result of a "gradual", rather long process composed of phases such as "deviation from school rules, not participating in school activities, becoming unsuccessful and leaving school " (cited by Sütçü, 2015:26). In this scope, students' not obeying school rules, not participating in school activities, not attending lessons, being absent from school from time to time and academic failure give educators information beforehand about the possibility that students might drop out of school. Under the light of all this data, in this study, it was aimed to determine bases of an intervention program which can be applied to learn non-attendance reasons of students and prevent their habitual non-attendance.

Method

In this study, case study, one of the qualitative research designs, was applied. In this design, one or more cases are investigated with a holistic approach via factors related to the situation. When forming the study group, maximum variation sampling, one of the purposeful sampling methods, was used. Semi-structured interview forms were used as data collection tools based on the responsibility areas of the participants in student non-attendance. The data was evaluated via the content analysis technique. The content analysis is used to reveal concepts and relationships required for the explanation of data (Şanll, Altun and Tan, 2015).

Results

The findings obtained in the research process indicate that the great majority of the participants reported that habitually non-attendant students' families' socio-economic levels were low; these students' mothers were illiterate and their fathers were primary and secondary school graduates; warning letters for absenteeism were frequently sent to achieve the students' school attendance and home visits were made; among the primary reasons for the students' habitual absenteeism were their 
frequently being unsuccessful and having a friends' group; all the parties had important contributions to the achievement of school attendance. Moreover, the great majority of the participants found what was done within the framework of regulations insufficient; most of the participants suggested the followings to achieve the students' school attendance: firstly penal sanctions should be applied; secondly, students should be given an instructive program about the matter of absenteeism, students' addresses should be accessible and families should be given trainings; a program or a project to be prepared with the aim of preventing students' habitual absenteeism should include school approach, school environment and the themes of student and family.

\section{Discussion}

The research findings indicated that the primary reasons for the students' habitual absenteeism were their frequently being unsuccessful in their lessons and having a friends' group. Rumburger (2001:10) discussed factors affecting students' absenteeism in four groups. These are family, school, society and peers. In the same study, it was determined that students' success in lessons have a direct effect on their school attendance and attitudes toward school. Moreover, it was also determined that the lack of activities and programs which students participated in after school and insufficient play grounds increased the peers' negative effects about school absenteeism. That insufficient possibilities of schools was one of the reasons for students' habitual absenteeism was also revealed in the study made by Aküzüm, Yavaş, Tan and Uçar'ın (2015). Moreover, Sütçü (2015) found that the students having difficulty in academic subjects for various reasons left school; that is to say, as success level decreased, the risk of leaving school increased.

In the study where school dropout prevention and intervention programs were evaluated, Wilson, Tanner-Smith, Lipsey, Steinka-Fry and Morrison'un (2011) reported that children of immigrant families with low socio-economic level are at risk of school absenteeism. The result reached in the present study that among the reasons for the students' habitual absenteeism placed the second the parents' having their children work and placed the third the students' having financial impossibilities verifies this result.

\section{Conclusion}

In conclusion, education, one of the basic human rights, is regarded by the World Bank (1993) as the catalyst of human development and economic growth (cited by Okumu, Nakajjo \& Isoke, 2008) and by researchers as a requirement for socio-economic development and life quality (King, N., Dewey, C., \& Borish, D., 2015). On the other hand, the study results indicate that family's educational and income level, the indicator of socio-economic status, is the strongest determinant of school success and attendance (Rumburger, 2001:14). In the Ninth National Education Council (1974), it was asserted that "in the basic education period, training the child together with his friends in his own age group is an invariable objective; all of such elements as teacher, programs and rules regulating student flow are changeable and a tool in the task of training the child" (YSÖP Instruction and Application Guideline, 2010:3). While there was such an approach for school attendance many years ago, still looking for ways to prevent school absenteeism today indicates that not a substantial ground has been covered yet. 